\title{
3 \\ Placing Sri Lankan maritime arrivals in a broader migration context
}

\section{Dinuk Jayasuriya and Marie McAuliffe†}

Our examination of irregular maritime arrival (IMA) flows to Australia from Sri Lanka places emphasis on both origin country and global migration dynamics. This approach recognises broader migration and mobility that a more asylum-/refugee-specific focused approach has the potential to either underemphasise or miss entirely. Taking a broader view also has the potential to allow for a greater appreciation of Australia's comparative position in a global context, which is perhaps useful given the, at times, 'Australia-centric' view of IMA flows.

This chapter places the unusual 2012 'spike' of Sri Lankan IMAs to Australia in a broader migration context as a means to better understand the Sri Lankan migration dynamics at both the macro level and at the micro (i.e. individual) level. It does not delve into all aspects of Sri Lankan migration-such as the irregular migration of migrant workers, for example—which, while potentially interesting, are beyond the scope of this chapter.

1 The authors are grateful for research assistance from Simone Gangell, Paul Hayes and Victoria Mence in the preparation of this chapter. 
We draw on two surveys undertaken in January and May of 2013, of 8,800 people in Sri Lanka, to show that while potential irregular migrants indicated that they would like to travel for reasons such as wanting a better future and economic prosperity, which are conceivably similar to those of regular migrants, these are not the only reasons. Rather, consistent with recent literature, our chapter paints a multidimensional picture showing that some potential irregular migrants from Sri Lanka wanted to travel for economic reasons and/or due to allegations of torture and persecution. ${ }^{2}$

The provision of information and evidence of Sri Lanka's place in a global migration context (including historically), as well as how some Sri Lankans view irregular migration, hopefully provides some illustration of why a strong appreciation of time and place in migration dynamics is important in improving our understanding of migration patterns and processes. This chapter does not attempt to cover all aspects related to Sri Lankan IMA flows in more recent times. It does, however, draw on a range of data and information relevant to the development of a deeper understanding of the events of 2012, when thousands of Sri Lankan IMAs travelled to Australia.

\section{Sri Lanka and migration}

Migration flows of Sri Lankan citizens to other countries can be broadly grouped into the following categories: temporary work (skilled, semiskilled and unskilled workers); settlement (mostly skilled migrants); education (mainly for tertiary studies); political reasons (asylum seekers); and tourism, including pilgrimages to India and Nepal (International Organization for Migration [IOM] \& Institute of Policy Studies of Sri Lanka [IPS], 2008).

Sri Lankan nationals who exit Sri Lanka are required to complete an embarkation card, and foreigners an arrival card for surrender to immigration officials. There are only a small number of entry/exit points for managing passenger movements in Sri Lanka, including one major and one minor international airport located in Colombo and a recently constructed international airport in the country's south. There are seven major sea ports around the country (Department of Immigration and Emigration [DIE], 2013).

2 These allegations are not necessarily of state-sponsored torture and persecution. 
In 2011, Sri Lanka recorded 1,206,135 arrivals of Sri Lankan citizens and 1,235,228 departures (DIE, 2011a; 2011b). Of those Sri Lankans departing, 262,960 (21 per cent) were for foreign employment (Bureau of Foreign Employment [BFE], 2012).

\section{Sri Lankan temporary and permanent emigration for employment}

In 2011, 262,960 Sri Lankans departed for work abroad with an almost linear increase between 1990 and 2011 (refer Figure 3.1). This growth exceeds population growth; departures for employment increased 305 per cent between 1991 and 2011, compared with a 20 per cent growth in Sri Lanka's population over the same period (BFE, 2011; World Bank, 2013a). In 1991, 0.38 per cent of the population travelled overseas for work, increasing to 1.26 per cent of the population in 2011. Sri Lankans departing for employment outside Sri Lanka are required to register with the Sri Lanka Bureau of Foreign Employment.

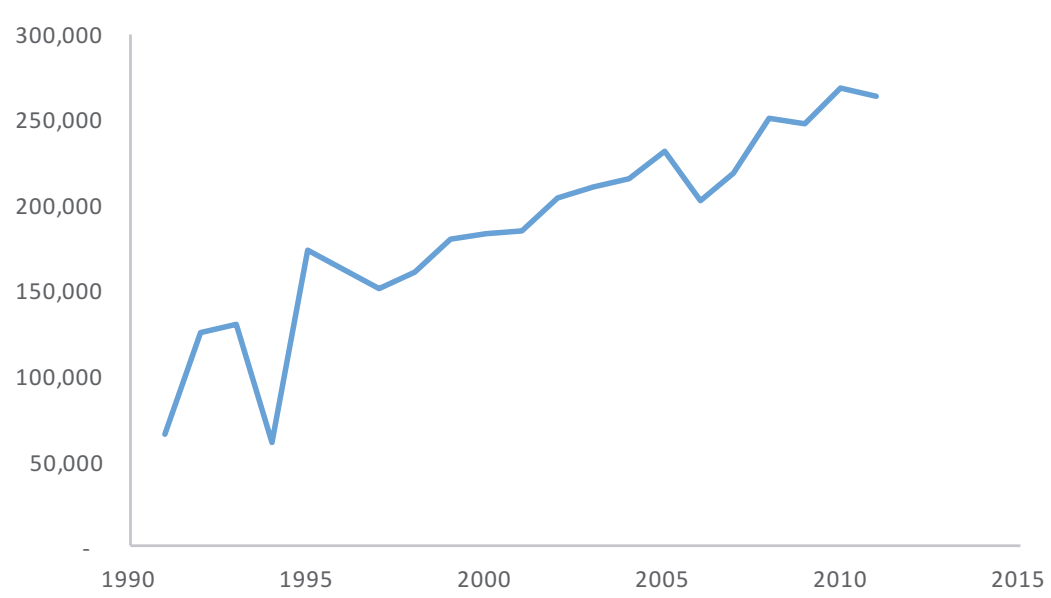

Figure 3.1: Departures for foreign employment

Source: Adapted from BFE (2012).

In 2010, almost 90 per cent of Sri Lankan men and almost 94 per cent of Sri Lankan women who sought temporary or permanent emigration for employment did so in the Middle Eastern countries of Saudi Arabia, Qatar, Kuwait, Lebanon, Jordan, Oman, Bahrain and the United Arab Emirates (DIE, 2010). 
The importance of these destination countries as sources of income is reflected in the increase in remittances from the Middle East since 1990. In 2011, remittances from the Middle East accounted for 60 per cent of total remittances to Sri Lanka (as shown in Figure 3.2).

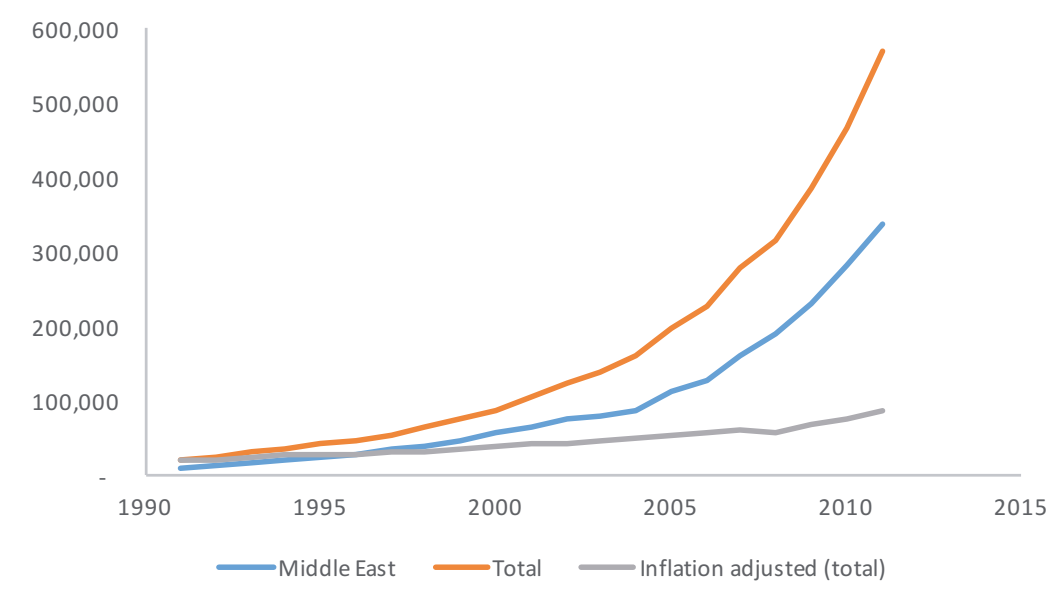

Figure 3.2: Remittances globally and from the Middle East

Source: Adapted from BFE (2012) and World Bank (2013a).

The increase in remittances has had a flow-on effect to the national economy, accounting for almost 50 per cent of export earnings in 2011 (BFE, 2012), and being approximately five times greater than the value of Foreign Direct Investments into Sri Lanka (World Bank, 2013a; World Bank, 2012).

\section{Sri Lankan emigration for study}

Education is very important for Sri Lankans, as demonstrated by the numerous newspaper, radio and billboard advertisements in Sri Lanka promoting potential places of study, both in Sri Lanka and overseas. A degree from a university outside of Sri Lanka is highly valued, with over 60 organisations, or 'education agents', providing advice on overseas study options (Australian Council for Private Education and Training, n.d.). Yet the absolute number of students travelling overseas for study to countries belonging to the Organisation for Economic Co-operation and Development (OECD) is relatively low. Table 3.1 shows a steady increase from 2004 until 2009, with Australia being the number one destination. Sri Lankans travelling overseas for study are not required to register with any government authority. 
Table 3.1: International students from Sri Lanka in OECD countries

\begin{tabular}{|l|r|r|r|r|r|r|}
\hline Destination & 2004 & 2005 & 2006 & 2007 & 2008 & 2009 \\
\hline Australia & 2,117 & 2,082 & 2,499 & 3,550 & 4,073 & 4,296 \\
\hline UK & 2,267 & 2,419 & 2,765 & 3,005 & 3,141 & 3,553 \\
\hline US & 1,964 & 2,081 & 2,234 & 2,425 & 2,594 & 2,927 \\
\hline Japan & 615 & 765 & 867 & 1,155 & 1,197 & 1,098 \\
\hline Canada & 161 & - & 252 & 186 & 271 & 309 \\
\hline Total & 7,603 & 7,855 & 9,125 & 10,915 & 12,049 & 13,065 \\
\hline
\end{tabular}

Source: Adapted from OECD (2012).

\section{Sri Lankan diaspora communities}

In 2010, there were nearly two million people in the Sri Lankan diaspora, with approximately 54 per cent of them living in the Middle East and approximately 34 per cent living in industrialised countries (World Bank, 2010). ${ }^{3}$ There are two distinct groups within this population. Sri Lankan Tamils constitute the overwhelming majority of diaspora communities found in industrialised countries, while migrant workers (such as those to the Middle East) are largely Sinhalese (International Crisis Group [ICG], 2010).

The Sri Lankan diaspora has been increasing steadily over the last decade. To illustrate, in OECD countries alone the diaspora has increased from an estimated 300,000 people in 2000 to almost 700,000 in 2010 (refer Figure 3.3).

The countries with the largest diaspora in 2010 were Canada, the UK, Italy and Australia (refer Table 3.2).

In 2010, Australia was ranked number four on the list with an estimated 78,098 people in the Sri Lankan diaspora. ${ }^{3}$ By mid-2013, the diaspora was estimated to be 130,000 by the Australian Department of Foreign Affairs and Trade (DFAT) (DFAT, n.d.). In 2011, the Sri Lankan community was the 13th largest migrant group in Australia, equivalent to 1.6 per cent of Australia's overseas-born population and 0.4 per cent of Australia's total population (Department of Immigration and Citizenship [DIAC], 2012). According to census data, around 50,151 Australians were Tamil speaking (Special Broadcasting Service [SBS], 2013).

3 World Bank and UN data only refer to Sri Lankan-born people and not people of Sri Lankan ancestry. 


\begin{tabular}{|c|c|c|c|}
\hline \multicolumn{4}{|l|}{600} \\
\hline \multicolumn{4}{|l|}{500} \\
\hline \multicolumn{4}{|l|}{400} \\
\hline \multicolumn{4}{|l|}{300} \\
\hline \multicolumn{4}{|l|}{200} \\
\hline \multicolumn{4}{|l|}{100} \\
\hline \multicolumn{4}{|c|}{2000} \\
\hline \multicolumn{4}{|c|}{$\begin{array}{l}\text { Figure 3.3: Sri Lankan diaspora in all OECD countries, 2000, } 2006 \\
\text { and } 2010 \\
\text { Source: OECD (2012) and adapted from World Bank (2010). }\end{array}$} \\
\hline \multicolumn{4}{|c|}{ Source: OECD (2012) and adapted from World Bank (2010). } \\
\hline Rank & Country & & Diaspora in 2010 \\
\hline 1 & Canada & & 123,012 \\
\hline 2 & UK & & 113,448 \\
\hline 3 & Italy & & 79,400 \\
\hline 4 & Australia & & 78,098 \\
\hline 5 & Germany & & 47,813 \\
\hline 6 & France & & 43,712 \\
\hline 7 & US & & 34,572 \\
\hline 8 & Switzerland & & 25,186 \\
\hline 9 & Norway & & 11,561 \\
\hline 10 & Netherlands & & 9,727 \\
\hline
\end{tabular}

Source: World Bank (2010).

\section{Sri Lankan Tamil diaspora}

Prior to Sri Lankan independence in 1948, there were some Sri Lankan Tamils living in Malaysia and Singapore, primarily as migrant workers in British Malaya (ICG, 2010). It was only after the 1983 riots that Tamils migrated en masse, largely as refugees to industrialised countries. Currently, there are estimated to be approximately one million Sri Lankan Tamils residing outside Sri Lanka, which is substantial when considering 
the Sri Lankan Tamil population in Sri Lanka is 2.3 million people (ICG, 2010; Department of Census and Statistics, 2012). Countries with significant (estimated) Sri Lankan Tamil populations include: Canada (200,000-300,000); UK (180,000); Germany (60,000); Switzerland (47,000); Australia (40,000); France (40,000-50,000); US (25,000); the Netherlands (20,000); and Malaysia (20,000) (ICG, 2010). A smaller number of the Sri Lankan Tamil diaspora live in the Middle East, South Africa and the Gulf States.

\section{Diaspora and remittances}

Remittances from industrialised countries with a large Sri Lankan diaspora have increased rapidly in the recent past, from USD1,429 million in 2010 to USD1,776 million in 2011 and USD2,161 million in 2012 (refer Figure 3.4). In 2012, remittances from the Sri Lankan diaspora in industrialised countries represented 34 per cent of all remittances globally.

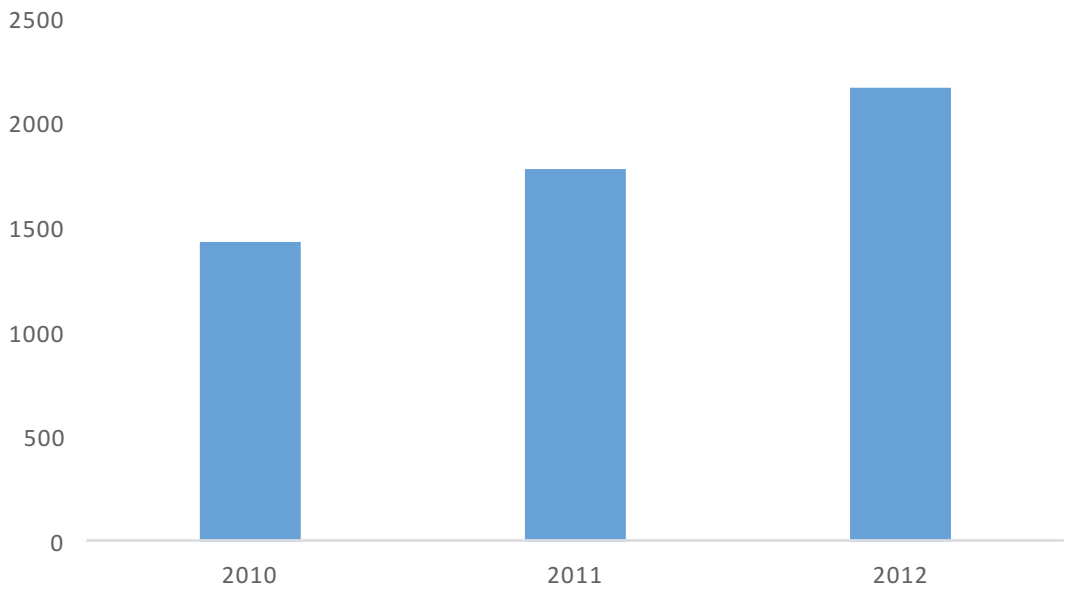

Figure 3.4: Remittances from OECD countries, 2010, 2011 and 2012 Source: Adapted from World Bank (2011, 2012, 2013b).

As might be expected, the top 10 industrialised countries for the Sri Lankan diaspora (for 2010) feature in the top 10 sources of remittances from industrialised countries (for 2012), almost in the same order (refer Tables 3.2 and 3.3). What is surprising is that the average remittance per person from OECD countries in 2010 was USD2,281, which was only slightly lower than the average remittance per person of USD2,329 from Middle Eastern countries. 
Table 3.3: Top 10 sources of remittances to Sri Lanka, 2012 (industrialised countries only)

\begin{tabular}{|l|l|r|}
\hline Rank & Country & Remittances (millions USD) \\
\hline 1 & Canada & 444 \\
\hline 2 & UK & 399 \\
\hline 3 & Australia & 279 \\
\hline 4 & Italy & 272 \\
\hline 5 & Germany & 173 \\
\hline 6 & France & 154 \\
\hline 7 & US & 132 \\
\hline 8 & Switzerland & 99 \\
\hline 9 & Norway & 48 \\
\hline 10 & Netherlands & 36 \\
\hline
\end{tabular}

Source: World Bank (2013b).

Prior to the defeat of the Liberation Tigers of Tamil Eelam (LTTE), the diaspora contributed an estimated USD200 million a year to the LTTE (ICG, 2010). For the past 25 years, the Sri Lankan Tamil diaspora has contributed to shaping the Sri Lankan political landscape through its financial and ideological support of the armed struggle for an independent Tamil state. Many in the diaspora were thought to have supported the LTTE; however, others were allegedly subject to extortion, intimidation and physical violence in order to silence criticism and secure financing (Human Rights Watch [HRW], 2006).

\section{Sri Lanka and asylum seekers and refugees: Source, transit and destination}

Given its recent past, Sri Lanka has primarily been a 'source' country of asylum seekers and refugees. That said, the labelling of 'source', 'host', 'transit' and 'destination' countries can be multidimensional, with countries fulfilling several of these broad categories at the one time. In addition, countries can quickly move from one category to another depending on prevailing security and political circumstances. Syria, for example, was until relatively recently a major 'host' country, primarily of Iraqi refugees; whereas it is now a major 'source' country due to the severity of its civil conflict. 


\section{Asylum seekers and refugees in Sri Lanka}

Sri Lanka is not a party to the 1951 Refugee Convention or its 1967 Protocol, nor does it have specific legislation or administrative mechanisms governing asylum and refugee affairs. The Sri Lankan Government relies on the United Nations High Commissioner for Refugees (UNHCR) to register and assess asylum seekers. The UNHCR has been involved in Sri Lanka since 1987 when the organisation was invited by the Sri Lankan Government to facilitate large-scale repatriation of Sri Lankan refugees from India. The UNHCR, under an agreement with the government, undertakes refugee status determination processes in Sri Lanka.

According to UNHCR data, there are (at any one time) only a small number of asylum seekers and refugees in Sri Lanka. At the end of 2012, there were 110 refugees and 263 asylum seekers registered in Sri Lanka (UNHCR, 2013). UNHCR data on asylum applications submitted in Sri Lanka between 2005 and 2012 shows that the vast majority of asylum seekers were Pakistani. Data also reveals that there has been a slight increase in asylum applications over the last two years (as shown in Figure 3.5) from non-Pakistani applicants.

Refugees are not permitted to reside or work in Sri Lanka, and very few refugees choose to repatriate back to their country of origin. Resettlement, therefore, remains the main durable solution for them. In 2012, 178 refugees in Sri Lanka were resettled to the US and Canada (UNHCR, 2013).

According to some in the Sri Lankan Government, Sri Lanka is increasingly becoming a transit and destination country for irregular migrants and asylum seekers, as reflected in recent public comments by Sri Lankan ministers on the 'deportation' of asylum seekers in Sri Lanka (Powell, 2013). According to the Sri Lankan Department of Immigration and Emigration, Sri Lanka has become a transit country for asylum seekers from Pakistan and Afghanistan trying to reach Australia (Integrated Regional Information Networks [IRIN], 2012b). 


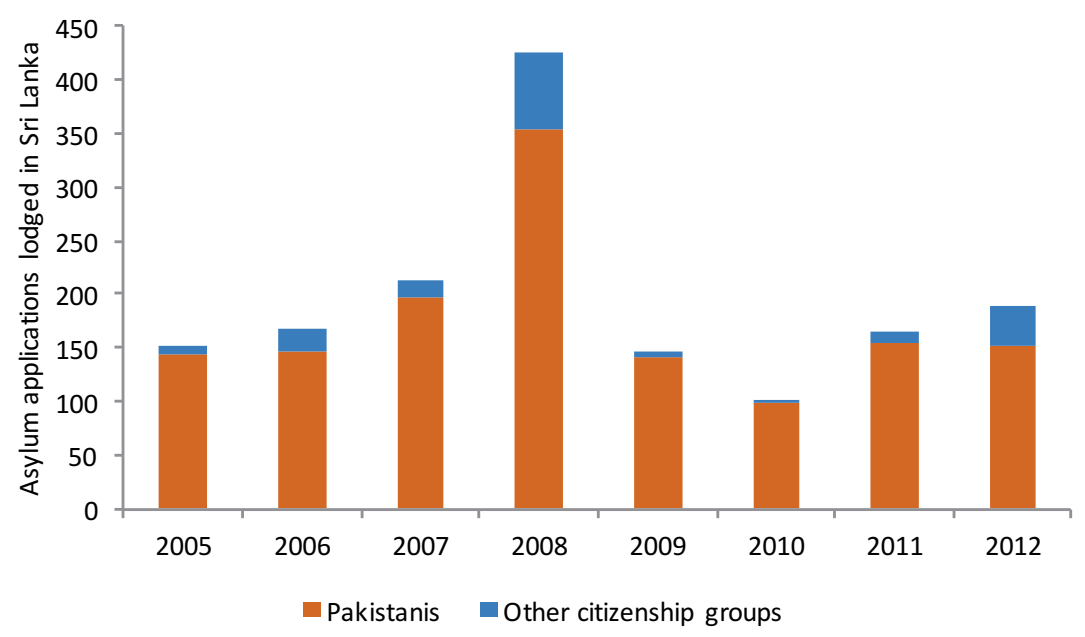

Figure 3.5: Asylum applications submitted in Sri Lanka, 2005-12 Source: UNHCR (n.d.).

\section{Internally displaced persons in Sri Lanka}

The number of internally displaced persons (IDPs) in Sri Lanka has gradually reduced since the end of the civil conflict in 2009. UNHCR has estimated that by the end of September 2012, some 468,000 people had returned to their places of origin (UNHCR, 2013). The closure in September 2012 of the government's 700-hectare IDP site 'Menik Farm' in northern Vavuniya district (the largest operational camp) highlighted the post-conflict transition that has occurred over time as people have gradually been resettled. At its peak, 'Menik Farm' housed 225,000 people (UNHCR, 2012). As of December 2012, 9,800 remained in IDP camps throughout Sri Lanka (Internal Displacement Monitoring Centre [IDMC], 2013).

Estimates of the number of IDPs in Sri Lanka have varied. The main sources of internal displacement statistics are government and the United Nations Office for the Coordination of Humanitarian Affairs (OCHA). As of January 2011, the OCHA estimated that around 273,772 Sri Lankans continued to be displaced (Association of Tamils of Sri Lanka in the USA, 2012). Some months on, IDMC (2013) estimated that (at 31 December, 2011), around 95,000 people were still displaced in Sri Lanka. IDMC noted that the Sri Lankan Government has kept some IDPs' areas of origin closed because of national security and/or danger to the public, including 
because of incomplete landmine clearance activity. As of the end of 2012, there were 93,447 IDPs, including people living inside and outside of camps (UNHCR, 2012). Given the substantial numbers of people that have been internally resettled, the UNHCR has indicated in its South Asia operations profile that during 2013 it will continue to promote the reintegration of refugee and IDP returnees, while winding down its direct engagement in the IDP situation (UNHCR, 2013).

\section{Sri Lankan asylum seekers and refugees around the world}

Sri Lanka's history of civil conflict is reflected in its status as a significant source country of asylum seekers and refugees. Given the nature of the civil conflict, Sri Lankan asylum flows have mainly comprised Tamils. According to UNHCR, as of December 2012, there were 132,749 Sri Lankan refugees and 13,975 asylum seekers worldwide (UNHCR, 2013). This placed Sri Lanka in the top 18 origin countries of the world's asylum seekers and refugees.

India has historically been, and continues to be, the main host country of Sri Lankan refugees. At the end of 2012, it hosted some 67,165 Sri Lankan (predominantly Tamil) refugees (UNHCR, 2013). The majority of India's UNHCR-registered Sri Lankan refugees lived in around 100 camps in the southern Indian state of Tamil Nadu. However, estimates of the number of Sri Lankans with pending asylum claims in Tamil Nadu vary considerably between organisations, from around 100,000 to 200,000 (ICG, 2010; IRIN, 2012a).

Outside of the thousands of Sri Lankan refugees hosted in India, Sri Lankan asylum seekers historically have travelled to specific destination countries. As shown in Table 3.4, the main asylum destination countries in 2012 were Australia, Malaysia, UK, France, Switzerland and Canada. These countries all have significant Sri Lankan diaspora.

Sri Lankan asylum claims in industrialised countries dropped from a high of about 14,500 applications in 2001 to around 5,500 per year between 2003 and 2006 (when there was a ceasefire between Sri Lanka and the LTTE). The UK, Canada and France collectively received 71 per cent of Sri Lankan asylum claims in 2001 (more than 10,000 of the 14,500 applications). In the lead-up to the end of the civil war in 2009, Sri Lankan asylum claims grew, as shown in Figure 3.6. 
A LONG WAY TO GO

Table 3.4: Sri Lankan global asylum applications, 2012 (selected countries)

\begin{tabular}{|l|r|}
\hline Destination & Asylum applications in 2012 \\
\hline Australia & 2,309 \\
\hline Malaysia & 1,910 \\
\hline UK & 1,840 \\
\hline France & 1,738 \\
\hline Switzerland & 1,610 \\
\hline Canada & 1,189 \\
\hline Germany & 994 \\
\hline Japan & 476 \\
\hline Indonesia & 404 \\
\hline Korea & 232 \\
\hline Nauru & 216 \\
\hline Netherlands & 140 \\
\hline
\end{tabular}

Source: UNHCR (n.d.).

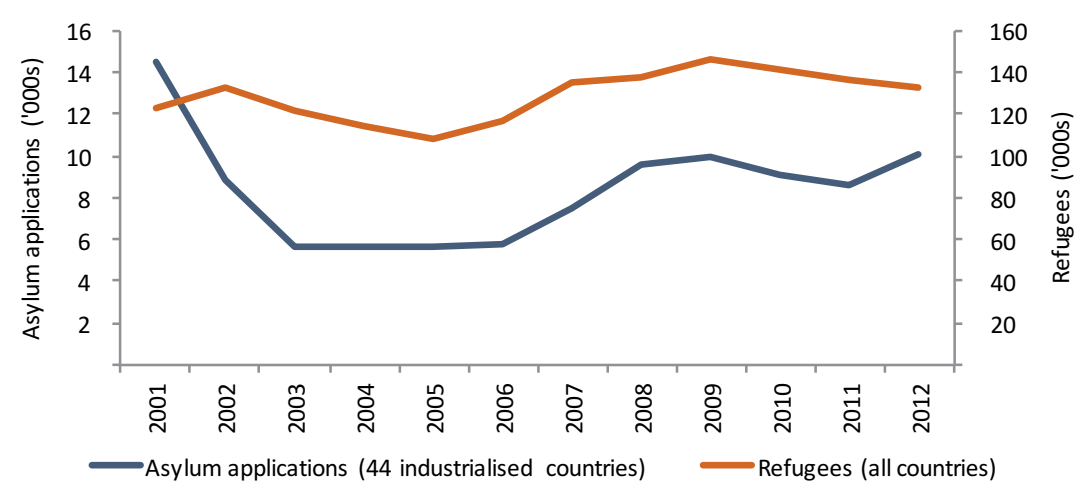

Figure 3.6: Sri Lankan asylum seekers and refugees, 2001-12

Source: UNHCR (2013); UNHCR (2002-13); UNHCR (n.d.).

\section{Regular and irregular migration of Sri Lankans to Australia}

As is the case with most other citizenship groups, the vast majority of Sri Lankan arrivals enter Australia on temporary visas, as can be seen in Figure 3.7. In 2012-13, 22,503 temporary entry visas were granted 
to Sri Lankan nationals, with visitors accounting for 73 per cent of visas granted. Other categories included student visas $(2,899$ or 13 per cent) and temporary work visas (1,014 or 5 per cent).

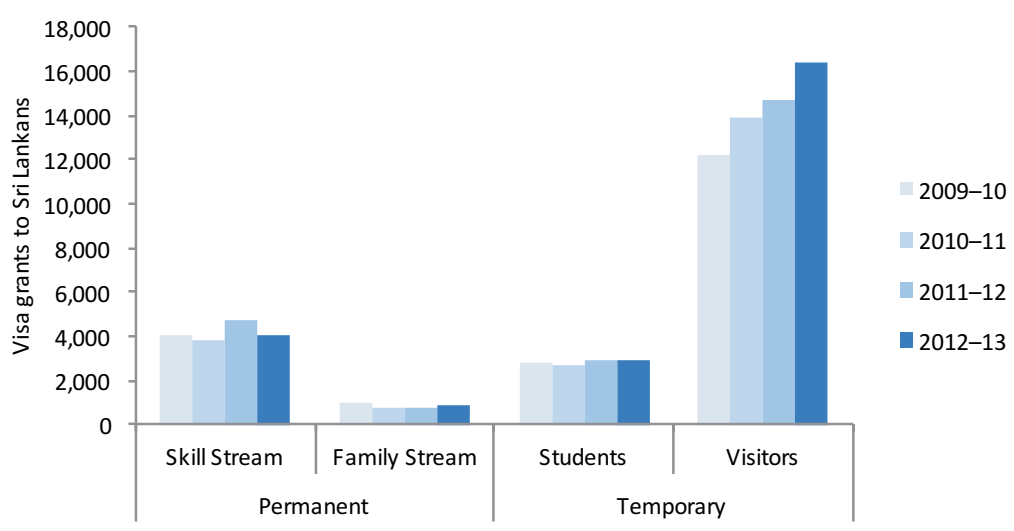

Figure 3.7: Australian visas granted to Sri Lankans, 2009-10 to 2012-13 Source: DIAC (2013).

\section{Sri Lankan permanent migration to Australia}

Sri Lankans first started emigrating to Australia in large numbers in the mid-1980s as a response to protracted conflict between the LTTE and government forces. Even though hostilities have formally ceased, the number of Sri Lankans choosing to live in Australia has continued to grow, with almost 5,000 Sri Lankans in 2012-13 migrating under Australia's Migration Program (comprising the Family and Skill Streams), compared with 2,000 a decade ago. Since 2007-08, Sri Lanka has consistently been one of Australia’s top 10 source migrant countries.

Skilled migration remains the main route for Sri Lankan nationals seeking permanent residency in Australia, accounting for 80 per cent of permanent visas granted to Sri Lankan nationals under the Migration Program in the decade to 2012-13. Sri Lankans were ranked eighth out of 175 citizenship groups granted visas under the Migration Program's Skill Stream in 2012-13, with 4,078 skilled visas granted to Sri Lankans.

The majority of Sri Lankan skilled migrants arrive under the General Skilled Migration (GSM) component of the Skill Stream, which provides permanent residence to skilled migrants who do not have an employer sponsoring them. In 2012-13, 3,228 GSM visas were issued 
to Sri Lankans, representing 79 per cent of all permanent skilled visas for Sri Lankans in that year. The main occupations of those granted a GSM visa included information and communications technology professionals, accountants, and engineering professionals.

Family migration to Australia facilitates the entry of close family members of Australian citizens, permanent residents and eligible New Zealand citizens. In 2012-13, 883 Sri Lankan nationals were granted permanent residency under the Migration Program's Family Stream, ranking 13th among 176 citizenship groups represented in the Family Stream in that year.

Australia's Humanitarian Program is designed to ensure Australia can respond effectively to global humanitarian situations and that support services are available to meet the specific needs of these entrants. Sri Lankans have not been a major source group for Australia’s Humanitarian Program, with just over a thousand Sri Lankans resettled under this program over the last 10 years. The majority (around 75 per cent) of visas granted to Sri Lankans under the offshore Humanitarian Program over the last five years were to the immediate ('split') family of Sri Lankan IMAs under the Special Humanitarian Program (SHP).

In 2012-13, 363 Sri Lankans were granted onshore protection visas (including both IMAs and non-IMAs), and 40 were granted offshore protection visas. The number of offshore resettlement grants to Sri Lankan citizens has decreased by 55 per cent from 88 in 2011-12. This accorded with previous years: 288 granted in 2010-11; 184 in 2009-10 and 215 in 2008-09, which is a reflection of the settling of hostilities since 2009. It is also a reflection of broader changes to the SHP. In addition, the number of onshore protection visas granted to Sri Lankans in 2012-13 has decreased by 14 per cent from the previous program year.

\section{Sri Lankan asylum seekers to Australia}

The significant decrease in Sri Lankan asylum claims globally, from 2002 onwards, coincided with the 2002 signing of the permanent ceasefire agreement between the Sri Lankan Government and the LTTE. Global asylum claims began to rise again in 2008 as the conflict escalated in the lead-up to the LTTE defeat in 2009.

This was reflected in asylum applications made in Australia. In 2008-09, Sri Lankans who arrived regularly by air (non-IMAs) made 478 applications for asylum. Subsequently, Sri Lankan non-IMA 
applications have generally declined over time: 328 in 2009-10; 160 in 2010-11; 138 in 2011-12 and 169 in 2012-13, while overall non-IMA application numbers have increased. Sri Lanka was ranked 14th among non-IMA asylum nationalities in 2012-13.

In 2009, Sri Lankan IMAs to Australia also increased but subsequently decreased and remained at low levels. The very dramatic increase in Sri Lankan IMA flows to Australia in 2012, however, signalled a departure from previous trends and was out of step with Sri Lankan asylum claims globally. To place the increase in context, in 2011 there were just over 200 IMAs from Sri Lanka, whereas in 2012 more than 6,400 Sri Lankan IMAs arrived in Australia, most of whom arrived in the second half of the year (refer Figure 3.8).

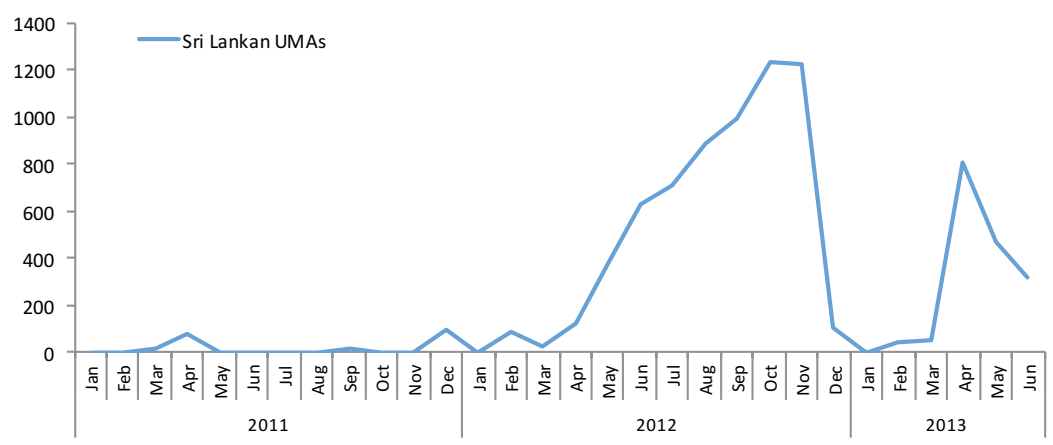

Figure 3.8: Sri Lankan irregular maritime arrivals, January 2011 - June 2013 Source: Department of Immigration and Border Protection (DIBP) (n.d.).

Note: By the end of 2012, many IMAs had not at that stage lodged applications for asylum, hence they were not captured in UNHCR asylum applications data in Table 3.4.

The large majority of IMAs from Sri Lanka were Tamils. However, in 2012, approximately 13 per cent of IMAs were Sinhalese, increasing from 0 per cent in 2011. Partly reflecting the changes in IMA dynamics and volume, returns to Sri Lanka following enhanced screening increased in volume. Between July 2012 and the end of May 2013, 162 voluntary and 965 involuntary returns to Sri Lanka occurred (Parliament of Australia, 2013).

In contrast to the Australian experience, other key Sri Lankan destination countries experienced decreases, plateaus or minor increases in 2012 (see Figures 3.9 and 3.10). Further to this, and unlike earlier IMA flows, in addition to protection issues, economic conditions and prospects were 
thought to be drivers for irregular maritime movement to Australia, especially for ethnic Sinhalese, who began arriving in significant numbers for the first time.

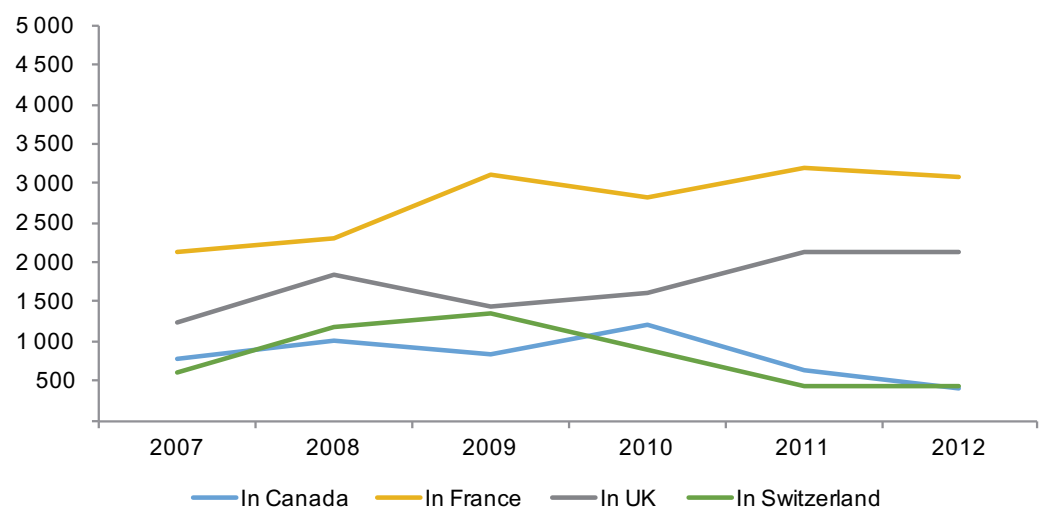

Figure 3.9: Sri Lankan asylum seekers: Key destination countries, 2007-12

Source: UNHCR (2002-13).

Figure 3.9 reveals the significant increase in Sri Lankan asylum seekers that occurred in Australia did not occur in other key destination countries. When Sri Lankan asylum applications submitted in all 44 industrialised countries are examined, a similar picture emerges (as shown in Figure 3.10).

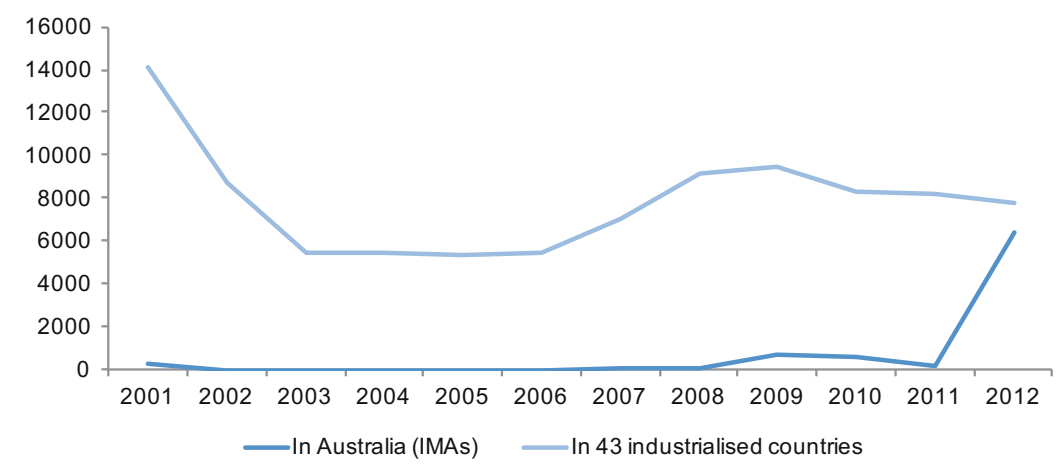

Figure 3.10: Asylum applications in 43 industrialised countries and IMAs, 2001-12

Source: UNHCR (2002-13); DIBP (n.d.).

Note: The 43 industrialised countries are all 44 industrialised countries listed in the UNHCR report except Australia. 


\section{Reasons potential irregular migrants from Sri Lanka choose to travel to destination countries}

In 2012, some people believed Sri Lankan IMAs entered Australia for economic reasons (March, 2012). This is hardly surprising, since literature suggests economic factors are an important reason people seek asylum (Neumayer, 2005), and Australia has been one of the few OECD countries where the economy has remained resilient throughout the global financial crisis (GFC). Others claimed Sri Lankans entered due to humanitarian reasons, citing political persecution and torture (Doherty, 2012). Yet, according to literature, the reasons were likely to be multidimensional (Monsutti, 2005), with neither economic prospects nor humanitarian issues representing the only reason for an IMA to enter Australia.

Surveys conducted in Sri Lanka during January and May 2013 under the Irregular Migration Research Program sought the views of potential irregular migrants themselves. Both surveys involved a pilot of over 400 people and a final survey of over 4,000 people using iPad technology (hence a total of 8,800 people were surveyed over two waves). Districts, the largest administrative unit in Sri Lanka, were selected based on source locations of irregular migrants. Simple random sampling was then employed to select Divisional Secretariats (DSs), the second largest administrative unit and Grama Niladhari (GNs), the lowest administrative unit. Households within GNs were selected randomly when possible. Data was weighted to consider nonresponse, ethnicity, IMA source location and gender. ${ }^{4}$

The surveys asked respondents about their intentions as they related to migration to Australia by boat. Based on responses to survey questions, respondents were then categorised according to degree of intention. In essence, 'non-intenders' indicated no intention to travel, 'intenders' expressed a desire to travel overseas by boat, 'active intenders' demonstrated

4 Male responses were given greater weighting than female responses (by a ratio of 89:11), as males overwhelmingly represent IMA. Greater weightings were also provided for districts that were source areas for IMAs. Ethnicity was weighted such that it was reflective of the populations in the districts surveyed (these were predominately Tamil, with all but one of the five districts surveyed having Tamil populations greater than 80 per cent). Areas with higher nonresponse were given greater weighting (although levels of nonresponse were largely consistent across districts). 
action by having made plans to travel and 'paid intenders' had made a payment towards such travel. ${ }^{5}$ The focus of the results presented in this chapter is on 'intenders', given the low sample sizes and hence relatively larger margins of error involved in analysing the subsamples 'active intenders' and 'paid intenders'.

\section{Intention to travel to Australia via irregular maritime migration}

Figure 3.11 illustrates reasons captured during the surveys as to why 'intenders' want to leave Sri Lanka and enter Australia. Note that the sample size is too small to allow categorisation according to ethnicity. ${ }^{6}$

A very high proportion of respondents (89 per cent) who were categorised as 'intenders' indicated that they desired to travel to Australia by boat for asylum to 'give their families a better future'. While acknowledging that this was a very broad response option that is multidimensional in nature, it is worth highlighting that the response reflects two key aspects in the decision-making of potential irregular migrants: a wish for a better future; and a desire to create that future for their families.

When this result is examined in conjunction with the next two highest ranking results_-Australia's job opportunities' (86 per cent) and 'lack of job opportunities in Sri Lanka' (84 per cent)—it is possible that many respondents view the attainment of a better future as being linked, in part, to employment and the ability to earn an income. The importance of remittances to the Sri Lankan economy and, therefore, Sri Lankan families, means that it is possible that 'giving their families a better future' includes family members that would remain in Sri Lanka.

5 In January 2013, 'intenders', 'active intenders' and 'paid intenders' represented an estimated 7.92 per cent, 1.46 per cent and 0.22 cent of the population in the districts surveyed respectively. This reduced to 4.53 per cent, 0.54 per cent and 0.16 per cent across 'intenders', 'active intenders' and 'paid intenders' respectively during the May 2013 survey.

6 'Intenders' represent a small percentage of the total sample and hence a further breakdown across ethnicity would increase the margins of error. 


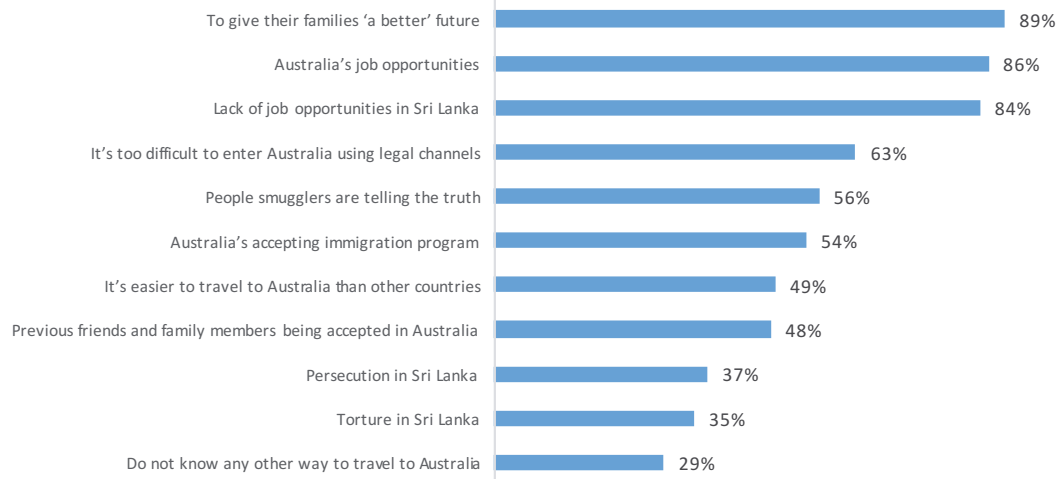

Figure 3.11: Reasons why 'intenders' want to leave Sri Lanka and enter Australia via boat

Source: 2013 Sri Lanka survey.

Economic factors, however, are unlikely to be the only reasons for wanting a better life. People who referred to persecution or torture amounted to almost 40 per cent of respondents. Notwithstanding the English definitions of 'torture' and 'persecution', these are ambiguous terms in Tamil and Sinhala. For example, 'torture' may refer to torture or violence from domestic partners rather than from state agents as might be assumed, while persecution may refer to Northern Tamils 'persecuting' Southern Tamils or vice versa with no consideration of whether or not the state could provide effective protection in such circumstances (Jayasuriya \& Gibson, 2013). Further research is required to gain a better understanding of potential irregular migrants' views on more precise meanings of 'torture' and 'persecution'.

The difficulties involved with entering Australia using legal channels (63 per cent) could be due to the requirements necessary for skilled and other migration, and the challenges of being accepted via Australia's Humanitarian Program. Further, while people smugglers are criminals and may lie to increase the number of clients, they may also have successfully facilitated previous transfers of irregular migrants to Australia via boat. This could point to the reason why 'people smugglers' are known as 'agents' by some Sri Lankans and why 56 per cent of 'intenders' believe people smugglers tell the truth.

It seems significant that over 50 per cent of people stated 'Australia's accepting immigration program' as a reason why they chose Australia as a destination. However, the most attractive features of the immigration 
policy have not been identified. Moreover, an 'accepting immigration program' could conceivably refer to the Skilled Migration Program, the numerous advertisements encouraging students to travel to Australia or possibly the way asylum seekers are treated in Australia. Further research is clearly required to determine which aspects of Australia's immigration program are most attractive.

The fact that 49 per cent of 'intenders' believe it is easier to travel to Australia than to other countries may be surprising, given the documented deaths of asylum seekers at sea and the close proximity to other potential countries such as India. However, many Sri Lankans living in coastal towns are fisherman, and hence spending two weeks to a month at sea, which is approximately how long it takes to travel from Sri Lanka to Australia by boat, is unlikely to be an issue. Note that while India is certainly easier to travel to than Australia, survey results indicate that India is not a 'preferred' destination (refer Figure 3.14).

That 48 per cent of 'intenders' say previous friends and family being accepted in Australia is a reason for wanting to travel to Australia is reasonable and consistent with similar studies highlighting the importance for asylum seekers of relatives who live in destination countries (Robinson $\&$ Segrott, 2002). Moreover, future asylum seekers may believe that they have similar chances of resettlement, that they will have an inside track on the process and that they potentially have a strong support network if they are granted protection.

While 29 per cent of 'intenders' state not knowing any other way to travel to Australia is a reason for travelling by boat, it is conceivable that more than 29 per cent actually do not know about other forms of traveleven if it's not a stated reason. Indeed, the chances of potential irregular migrants entering through regular programs are likely to be minimal.

\section{Examination of 'economic intenders'}

Economic factors were clearly one reason the large majority of people (approximately 85 per cent) intended leaving Sri Lanka to travel to Australia. Yet many of these people also had other reasons for travel, and it would be unwise to not recognise the multidimensional factors involved in migrant decision-making. 
To highlight this point, Figure 3.12 replicates Figure 3.11 but restricts the analysis to 'economic intenders' (those who stated they intended to leave Sri Lanka because of lack of job opportunities or intended to travel to Australia for job opportunities). Figure 3.13 shows 'economic intenders' also had other reasons for seeking asylum; i.e. these people are not only 'intenders' due to economic reasons.

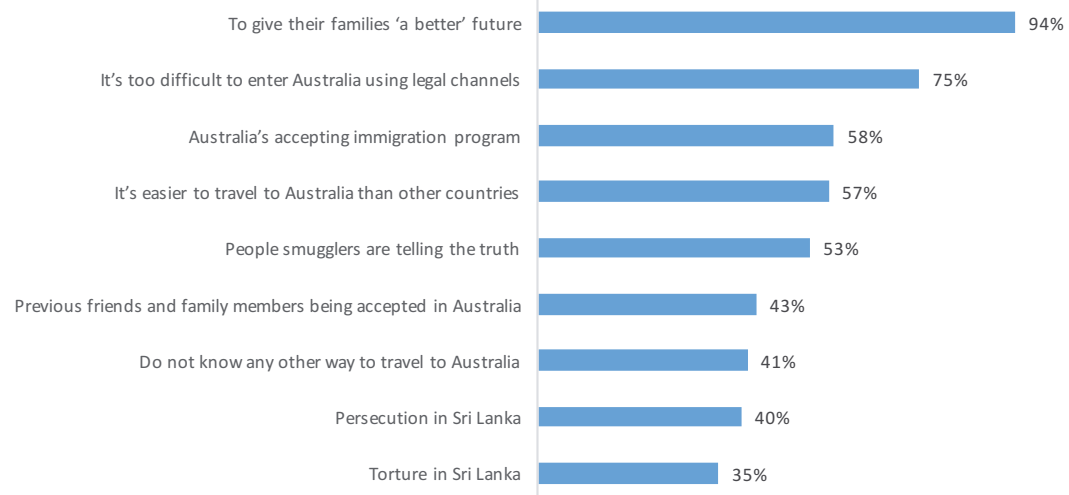

Figure 3.12: Reasons why 'intenders' wanted to leave Sri Lanka and why they wanted to enter Australia via boat-sample restricted to 'economic intenders'7

Source: 2013 Sri Lanka survey.

The reasons why 'economic intenders' desire to travel to Australia by boat (Figure 3.12) were similar to all 'intenders' (Figure 3.11). Of interest is that among 'economic intenders', those who referred to persecution or torture amounted to approximately 42 per cent, suggesting at least 58 per cent of the 'economic intenders' potentially wanted to travel to Australia for non-protection reasons.

A key limitation of this survey data is that analysis focuses on people with an 'intention' (i.e. 'intenders') to travel overseas for asylum and not people with a demonstrated 'action' (i.e. 'active intenders') or people who have 'committed' to travelling overseas for asylum (i.e. 'paid intenders'). Results relating to 'intenders', 'active intenders' and 'paid intenders' are likely to vary significantly. To illustrate, among 'active intenders' considering travelling to Australia for economic reasons, the number who referred to persecution or torture increased to 66 per cent, suggesting that the

7 Data was pooled from the January and May surveys to increase the sample size of 'intenders' to Australia; however, this still produces a margin of error of approximately 5.4 per cent. 
remaining 34 per cent may have intended travelling for reasons that did not overtly include protection-related concerns. Future research should consider a larger sample size that is likely to capture a larger absolute number of 'active intenders' and 'paid intenders'.

Additionally, Figures 3.11 and 3.12 list reasons why 'intenders' desire to travel to Australia by boat without demonstrating their relative importance. To illustrate, while economic reasons and persecution may be important drivers, the presence of family and friends in Australia may be a key determinant. Future research is required to analyse the relative importance of drivers and determinants. Finally, future research should consider presenting a more comprehensive list of possible factors influencing irregular migration.

\section{Australia relative to the rest of the world}

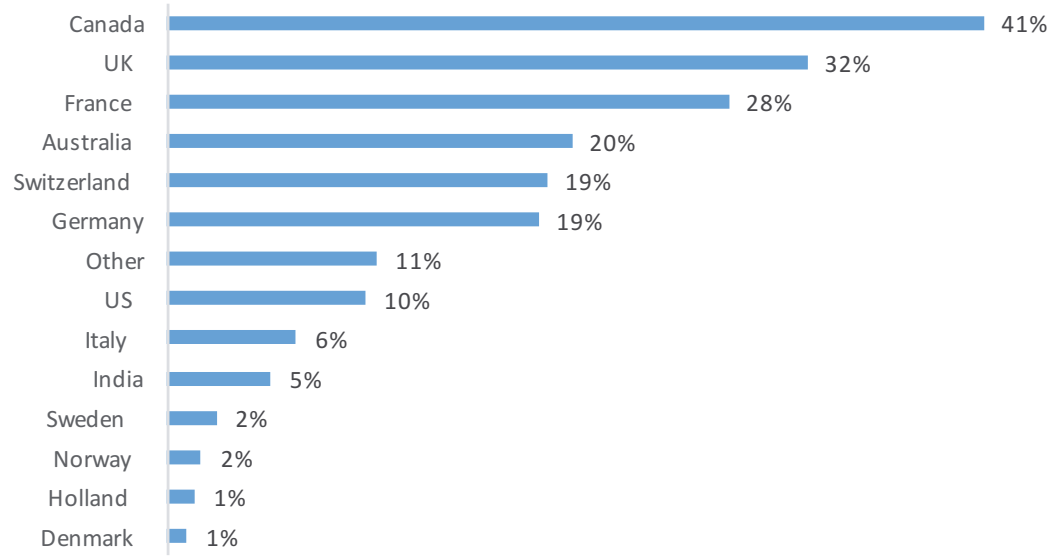

Figure 3.13: Intenders' preferred destinations

Source: 2013 Sri Lanka survey.

Note: Individuals could indicate a 'preference' to travel to more than one country while they have an 'intention' to travel to just one country. Results are subject to a margin of error of approximately 4.2 per cent.

The May 2013 survey data found that 41 per cent of 'intenders' wanted to travel to Canada for asylum, followed by the UK (32 per cent) and France (28 per cent). Australia ranked 4th out of 13 countries listed, at 20 per cent (refer Figure 3.14). This suggests that while Australia is still a preferred destination for asylum seekers from Sri Lanka, its importance may be diminishing. Australia's position relative to other countries could 
be due to a host of reasons including but not limited to geography, diaspora links, immigration policies and practices, and economic performance. Additional research is required to distil the relative importance of the multiple factors influencing decisions about potential migrants' preferred destinations.

Some reasons why 'intenders' wanted to travel to destination countries (anywhere in the world) are illustrated in Figure 3.14.

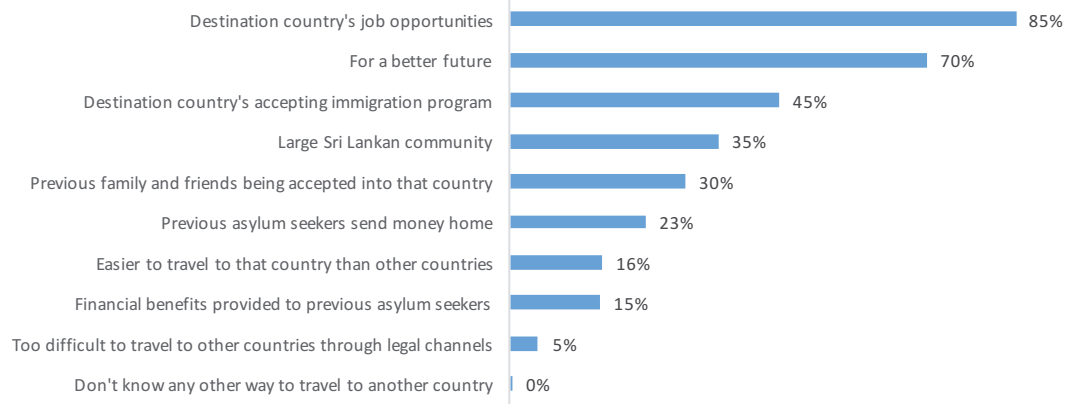

Figure 3.14: Reasons why 'intenders' are attracted to destination countries (all countries)

Source: 2013 Sri Lanka survey.

Note: Results are subject to a margin of error of approximately 4.2 per cent.

The results show that economic factors are the main reason 'intenders' are attracted to a destination country. Note that these options were not shown to respondents during the survey, suggesting results may be different if multiple-choice options were provided. For example, intuitively, ease of travel is an important reason why one might choose a certain country, yet only 16 per cent of people suggested this as an answer. Perhaps if respondents had been presented with pre-determined options, more people would have selected ease of travel. Further, unlike in Figures 3.9 and 3.10, the results also do not highlight why a person may want to leave Sri Lanka.

\section{Conclusions}

Many Sri Lankans travel overseas for regular and irregular migration purposes. In 2011, approximately 260,000 migrants travelled overseas for temporary or permanent employment opportunities. Most of the foreign workers were Sinhalese, and the large majority of Sinhalese workers 
migrated to Middle Eastern countries. In contrast, Tamils comprised the bulk of Sri Lanka's diaspora in industrialised countries, and made up the majority of asylum seekers and refugees.

In 2012, just over 15,000 Sri Lankans were asylum seekers globally, with Australia ranked as the number one destination. When focusing on IMAs, Australia experienced a highly unusual jump from under 100 arrivals from the first quarter of 2012 to around 2,600 in the third quarter of 2012. This number was also unusual when compared to asylum applications globally, with other countries experiencing decreases, plateaus or minor increases in 2012.

Surveys undertaken in high IMA source areas of Sri Lanka during January and May of 2013 revealed that the reasons people intended to travel by boat to Australia involved multiple, interrelated factors, including factors related to protection, visa access, employment, people smuggling, geography and family/community links. The most prominent factors related primarily to economic prosperity. This is unsurprising, given economic factors were also the primary reason for people desiring to travel to other countries. Of more interest is that, among people travelling for economic reasons, results show at least 58 per cent of people with a desire ('intenders'), and at least 36 per cent of people with plans in place ('active intenders'), to travel by boat to Australia, appeared to do so for non-protection reasons. That said, further research is required for a more precise analysis of the drivers and determinants of 'active intenders' and 'paid intenders'.

The survey findings are consistent with Koser's discussion of a paradigm shift involving the convergence of 'political refugees and economic migrants into a single migration route', as asylum seeking (Koser, 2001). Seeking asylum via irregular migration channels can be an effective strategy whereby people, including genuine asylum seekers, can gain a legitimate migration status relatively swiftly that would be virtually impossible to obtain by staying where they are or attempting to move via regular pathways.

The survey results in this chapter highlight the multidimensional factors potential irregular migrants take into account when assessing and reassessing whether to, and where to, migrate. Further examination of both potential and actual migrants' views (including IMAs) would allow for a deeper understanding of the drivers and motivations of those Sri Lankans 
who migrate irregularly by maritime means. Another useful research focus would be the possible decision-making factors involved in the decisions of potential irregular migrants not to migrate, including those who may be facing protection issues. Adhikari's research on the impact of a range of factors on potential refugee decision-making in Nepal highlights that individual decision-making, even in extreme conflict situations, is based on more than just the threat to one's life, and includes factors related to economic livelihoods and social networks (Adhikari, 2012).

\section{Reference list}

Adhikari, P. (2012). Conflict induced displacement: Understanding the causes of flight. American Journal of Political Science, 57(1), 82-89. doi.org/10.1111/j.1540-5907.2012.00598.x

Association of Tamils of Sri Lanka in the USA. (2012). 2012 UNHCR country operations profile-Sri Lanka. Retrieved April 19, 2012 from Ilankai Tamil Sangam: www.sangam.org/2012/04/UNHCR_ Profile.php.

Australian Council for Private Education and Training. (n.d.). Education agents in Sri Lanka. Retrieved July 15, 2013 from www.acpet.edu.au (service available only to members).

Bureau of Foreign Employment (Sri Lanka). (2011). Annual statistical report of foreign employment -2010. Colombo: Author.

Bureau of Foreign Employment (Sri Lanka). (2012). Annual statistical report of foreign employment -2011. Colombo: Author.

Department of Census and Statistics (Sri Lanka). (2012). Population by ethnic group according to districts, 2012. Retrieved July 2013 from Population \& housing data 2012 (provisional): www.statistics. gov.lk/PopHouSat/CPH2011/index.php?fileName=pop $42 \&$ $\mathrm{gp}=$ Activities\&tpl=3.

Department of Foreign Affairs and Trade (Australia). (n.d.). Sri Lanka country brief. Retrieved from dfat.gov.au/geo/sri-lanka/pages/srilanka-country-brief.aspx.

Department of Immigration and Border Protection (Australia). (n.d.). Unpublished data on irregular maritime arrivals, 2011-13. 
Department of Immigration and Citizenship (Australia). (2012). Country profile, Sri Lanka. Canberra: Author.

Department of Immigration and Citizenship (Australia). (2013). Statistics. Canberra: Author.

Department of Immigration and Emigration (Sri Lanka). (2010). Departures for foreign employment through all sources by country and sex 2006-2010 (provisional). Retrieved July 4, 2013 from National Centre for Migration Statistics: www.statistics.gov.lk/ncms/RepNTab/ Tables/SLBFE/tab9.pdf.

Department of Immigration and Emigration (Sri Lanka). (2011a). Arrivals by nationality and month-2011. Retrieved July 4, 2013 from National Centre for Migration Statistics: www.statistics.gov.lk/ NCMS/RepNTab/Tables/DIE/2011Arr.pdf.

Department of Immigration and Emigration (Sri Lanka). (2011b). Departures by nationality and month-2011. Retrieved July 4, 2013 from National Centre for Migration Statistics: www.statistics.gov.lk/ NCMS/RepNTab/Tables/DIE/2011Dep.pdf.

Department of Immigration and Emigration (Sri Lanka). (2013). About us/border management. Retrieved July 4, 2013 from www. immigration.gov.lk/web/index.php?option=com_content $\&$ view= article\&id=132\&Itemid=59\&lang=en.

Doherty, B. (2012, July 24). Sent home to 'arrest, torture'. Sydney Morning Herald. Retrieved October 10, 2013 from www.smh.com.au/federalpolitics/political-news/sent-home-to-arrest-torture-20120723-22kur. html.

Human Rights Watch. (2006). Funding the final war': LTTE intimidation and extortion in the Tamil diaspora. Retrieved from www.hrw. org/report/2006/03/14/funding-final-war/ltte-intimidation-andextortion-tamil-diaspora.

Integrated Regional Information Networks. (2012a). Sri Lanka: Tamil refugees slowly return from India. Retrieved July 16, 2013 from www.refworld.org/docid/4fofed552.html.

Integrated Regional Information Networks. (2012b). Sri Lanka: More people boarding boats to Australia. Retrieved July 16, 2013 from: www.irinnews.org/report/95855/sri-lanka-more-people-boardingboats-to-australia. 
Internal Displacement Monitoring Centre. (2013). Numbers of IDPs in Sri Lanka. Retrieved from www.internal-displacement.org.

International Crisis Group. (2010). The Sri Lankan Tamil diaspora after the LTTE. Asia Report No. 186. Colombo/Brussels: Author.

International Organization for Migration, \& Institute of Policy Studies of Sri Lanka. (2008). International migration outlook-Sri Lanka. Colombo: International Organization for Migration.

Jayasuriya, D., \& Gibson, J. (2013, February 28). Elephants, tigers and safety in post-conflict Sri Lanka. Development Policy Centre Discussion Paper No. 27. Canberra: The Australian National University.

Koser, K. (2001). New approaches to asylum? International Migration, 39(6), 85-102. doi.org/10.1111/1468-2435.00180

March, S. (2012, November 7). Sri Lankans heading to Australia 'economic migrants', not refugees: IOM. Retrieved from ABC News: www.abc. net.au/news/2012-11-06/an-sri-lankans-27economic-migrants272cnot-refugees $/ 4355860$.

Monsutti, A. (2005). War and migration: Social networks and economic strategies of the Hazaras of Afghanistan. New York and London: Routledge. doi.org/10.1525/ae.2006.33.4.4049

Neumayer, E. (2005). Bogus refugees? The determinants of asylum migration to Western Europe. International Studies Quarterly, 49(3), 389-410. doi.org/10.1111/j.1468-2478.2005.00370.x

Organisation for Economic Co-operation and Development. (2012). Key statistics on diaspora from Sri Lanka. Connecting with emigrants. Paris: Author. doi.org/10.1787/9789264177949-graph30-en

Parliament of Australia. (2013, 28 May). Commonwealth senate estimates, legal and constitutional affairs legislation committee hearing (pp. 52-53, 115-16). Canberra: Author. Retrieved from www.aph. gov.au/hansard.

Powell, L. (2013, March 17). Sri Lankan minister calls for deportation of Maldivian asylum seekers. Minivan News. Retrieved August 25, 2017 from minivannewsarchive.com/date/2013/03/17. 
Robinson, V., \& Segrott, J. (2002). Understanding the decision making of asylum seekers. Home Office Research Study 243. London: Home Office.

Special Broadcasting Service. (2013). Census explorer. Retrieved August 13, 2013 from www.sbs.com.au/yourlanguage/tamil/censusexplorer.

United Nations High Commissioner for Refugees. (2002-13). Asylum levels and trends in industrialized countries (various eds). Geneva: Author.

United Nations High Commissioner for Refugees. (2012). Sri Lanka's displacement nears end with closure of Menik Farm. Retrieved July 5, 2013 from www.unhcr.org/en-au/news/latest/2012/9/506443d89/srilankas-displacement-chapter-nears-end-closure-menik-farm.html.

United Nations High Commissioner for Refugees. (2013, March). UNHCR Sri Lanka Fact Sheet. Sri Lanka. Retrieved July 16, 2013 from www.unhcr.org/561681326.pdf.

United Nations High Commissioner for Refugees. (n.d.). UNHCR statistical online population database. Data extracted July 5, 2015. Retrieved from popstats.unhcr.org.

World Bank. (2010). Bilateral migration matrix 2009. Retrieved August 24, 2017 from www.worldbank.org/en/topic/migration remittancesdiasporaissues/brief/migration-remittances-data.

World Bank. (2011). Bilateral remittance matrix 2010. Retrieved August 24, 2017 from www.worldbank.org/en/topic/migration remittancesdiasporaissues/brief/migration-remittances-data.

World Bank. (2012). Bilateral remittance matrix 2011. Retrieved August 24, 2017 from www.worldbank.org/en/topic/migration remittancesdiasporaissues/brief/migration-remittances-data.

World Bank. (2013a). World development indicators. Retrieved August 24, 2017 from www.worldbank.org/en/topic/migration remittancesdiasporaissues/brief/migration-remittances-data.

World Bank. (2013b). Bilateral remittance matrix 2012. Retrieved August 24, 2017 from www.worldbank.org/en/topic/migration remittancesdiasporaissues/brief/migration-remittances-data. 
This text is taken from A Long Way to Go: Irregular Migration Patterns, Processes, Drivers and Decision-making, edited by Marie McAuliffe and Khalid Koser, published 2017 by ANU Press, The Australian National University, Canberra, Australia.

dx.doi.org/10.22459/LWG.12.2017.03 